\title{
Nearshore evolution at Noordwijk (NL) in response to nourishments, as inferred from Argus video imagery
}

\author{
B.G. Ruessink ${ }^{1}$, R.M. van der Grinten ${ }^{1}$, L. Vonhögen-Peeters ${ }^{2}$, G. Ramaekers ${ }^{3}$ and Q.J. Lodder $^{3}$ \\ ${ }^{1}$ Department of Physical Geography, Faculty of Geosciences, Utrecht University, P.O. Box 80.115, 3508 TC Utrecht, The \\ Netherlands, b.g.ruessink@uu.nl, www.coastalresearch.nl/gruessink \\ ${ }^{2}$ Deltares, Subsurface and groundwater systems, Utrecht \\ ${ }^{3}$ Rijkswaterstaat Waterdienst, Lelystad
}

\begin{abstract}
We use an approximately 16-year long data set of daily low-tide video images to examine the effect of three consecutive nourishments on the temporal evolution of the subtidal sandbars and the low-tide water line at Noordwijk, The Netherlands. The data set starts in 1995, with shoreface nourishments implemented in 1998 and in 2006, and a "Zwakke Schakel" beach nourishment in 2007/2008. We find that, consistent with observations elsewhere, the shoreface nourishments halted the interannual, net-seaward migration of the two sandbars. Also, the first nourishment resulted in large-scale sandbar variability known as bar switching. The beach nourishment had no effect on the sandbars, other than an immediate 50-m seaward shift of the low-tide waterline and the inner sandbar. Neither the shoreface nor the beach nourishments were found to result in an increase or decrease in the number and cross-shore extent of rip channels. On the whole, the successive nourishments have reduced the natural dynamics of the Noordwijk coastal system.
\end{abstract}

\section{INTRODUCTION}

Along some $70 \%$ of the Dutch coast wind-blown dunes are the last line of natural defense against high waves and water levels during storms. Every six years the safety of these dunes is assessed with an equilibrium-type dune-erosion model, see, for example, Den Heijer et al. (in press). A dune is then considered to be safe when it will not breach during a storm with an occurrence probability of 1 in 10.000 for a given year. Early this century, more than 10 locations along the Dutch coast were considered to be insufficiently safe, especially in view of expected changes in the hydrodynamic boundary conditions induced by climate change. Coastal safety at most of these so-called Zwakke Schakels (Dutch for Weak Links) has been enhanced by large-scale human measures, often including (beach) nourishments.

Noordwijk, located at the central Dutch Holland coast, is an example of a Zwakke Schakel. Here, in winter 2007-2008, the Dijk-in-Duin project was carried out, which involved a massive restructuring of the small and narrow dune field into a wider and higher dune row (see Figure 1). Within the new dune, a $1.1 \mathrm{~km}$ long, 9-m high dike was built. Furthermore, the beach was nourished with approximately $3 \mathrm{Mm}^{3}$ of sand over a length of 3 $\mathrm{km}$ alongshore. This implies a local seaward extension of the beach and the dunes of about $40-50 \mathrm{~m}$.

The nearshore zone of Noordwijk has been monitored with an Argus video-system since 1995. This has resulted in one of the longest (now 16 years), high-resolution (daily) data sets of nearshore evolution with and without human activities. The first 3 years of data contain information on the autonomous nearshore behaviour. In addition to the afore-mentioned Dijk-in-Duin project, shoreface nourishments were implemented in 1998 and 2006. The aim of this paper is to evaluate the effect of the various nourishments, including the Dijk-in-Duin nourishment, on the behaviour of the subtidal sandbars and on the low-tide water line.

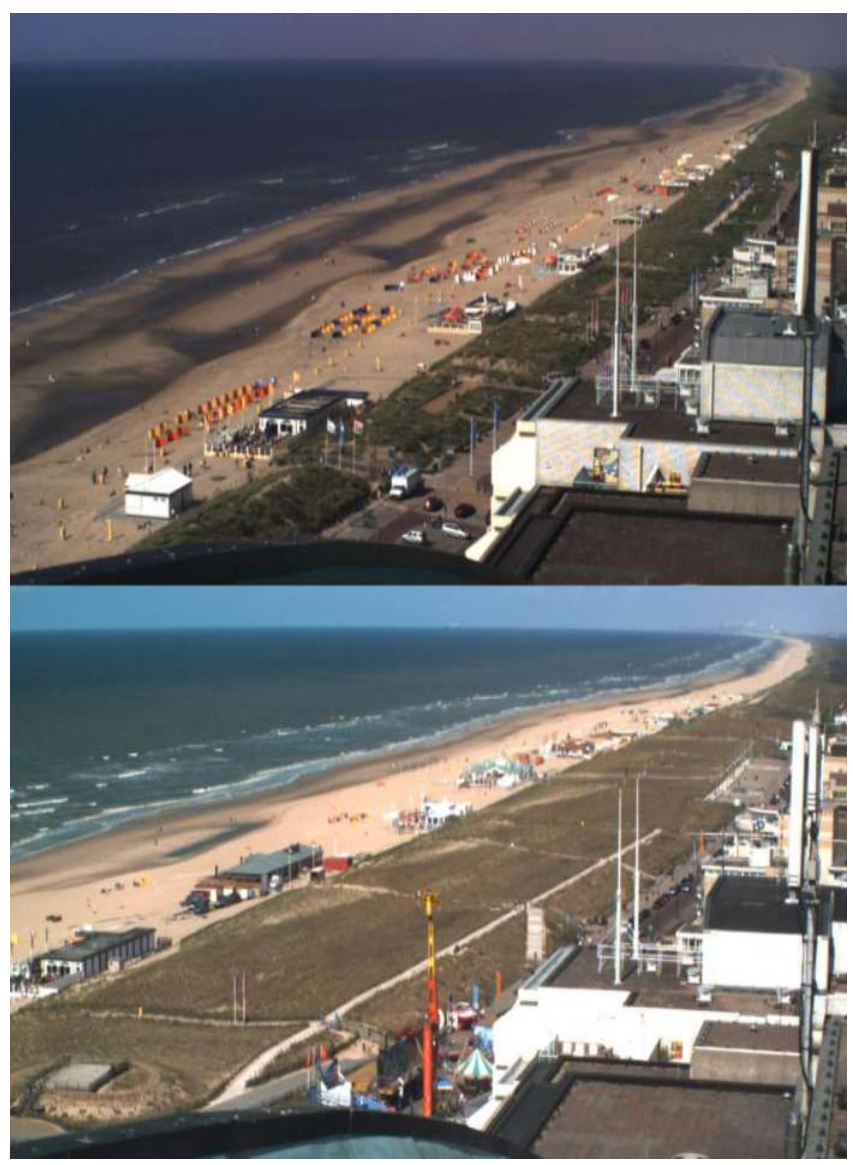

Figure 1. A picture of the dunes and beach at Noordwijk (top) before and (bottom) after the Dijk-in-Duin project. Note the striking seaward extension of the dunes and beach. 


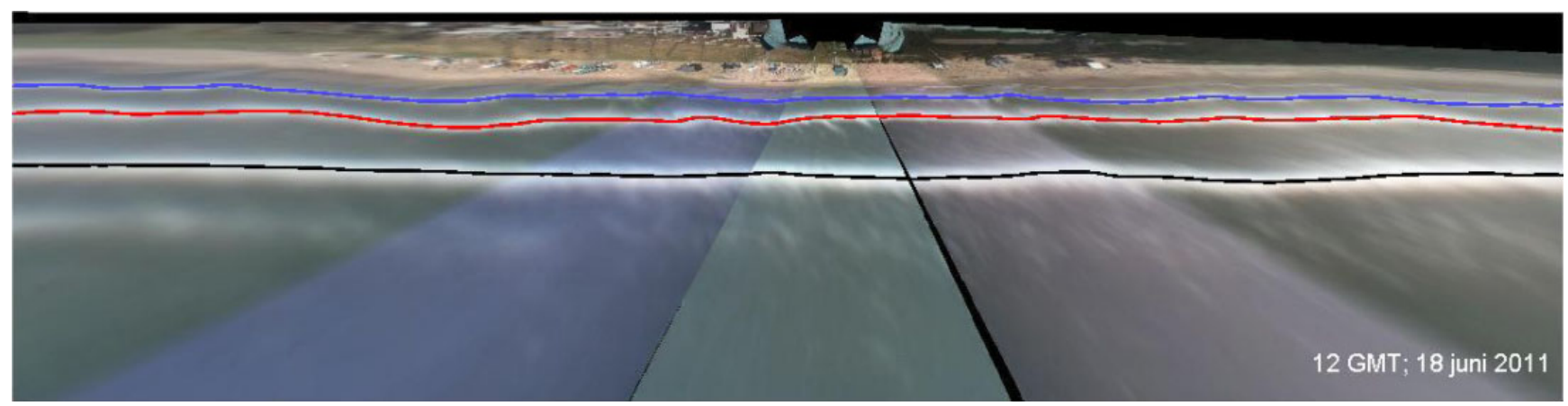

Figure 2. Planview image with an alongshore and cross-shore width of 6 and $1.5 \mathrm{~km}$, respectively. Pixel size is $2.5 \times 2.5 \mathrm{~m}$. The black, red and blue lines represent the location of the outer subtidal sandbar, the inner subtial sandbar, and the waterline, respectively. Just seaward of the outer bar, a faint breakerline (not tracked) indicates the position of the 2006 shoreface nourishment.

\section{METHODS AND RESEARCH QUESTIONS}

This study was based on the 10-minute time-exposure images collected hourly since 1995, when the Argus system was installed with 5 color cameras. Merging of the images collected during a given hour results in a planview image (Figure 2) that offers an uninterrupted view of the nearshore for some $6 \mathrm{~km}$ alongshore and $1.5 \mathrm{~km}$ cross-shore. The most striking features in a merged planview image are alongshore continuous, white, high-intensity bands that reflect the wave breaking on subtidal sandbars and nourishments, and on the beach face. These lines are most conspicuous at low tide and we therefore restrict our data set to images collected at low tide.

The alongshore positions of each breakerline were extracted for every available low-tide image in the period March 1995 - August 2011 using the methodology described in Van Enckevort and Ruessink (2001). The colored lines on top of the breakerlines in Figure 2 provide examples of the extracted lines, henceforth called barlines. These lines do not reflect the precise location of the crest of the underlying sandbars. Most importantly, the barlines will shift on/offshore in response to slight day-to-day variations in the low-tide level (Van Enckevort and Ruessink, 2001). These variations were removed following the approach of Pape et al. (2010). Using the obtained data set of barlines, we focused our analyses to answer the following 3 research questions:

1. What is the effect of the nourishments on the alongshoreaveraged position of the sandbars and on the low-tide waterline? This implies that we focus on the overall crossshore (i.e., uniform) sandbar and waterline motion in the entire 6-km width of the study area.

2. What is the effect of the various nourishments on largescale sandbar and waterline variability within the $6 \mathrm{~km}$ study area? Examples of such variability include sandbar switches (e.g., Ojeda et al., 2008) and shoreward propagating accretionary waves (e.g., Wijnberg and Holman, 2007).

3. What is the effect of the nourishments on small-scale sandbar and waterline variability? The focus here is on the number and cross-shore magnitude of rip channels.

\section{RESULTS}

\section{Uniform behavior}

Figure 3 summarizes our main results for the alongshoreaveraged position of the sandbars, the various nourishments and the low-tide water line. Prior to 1998, the two subtidal sandbars migrated offshore. This reflects the autonomous behavior along this stretch of coast (e.g., Wijnberg and Terwindt, 1995). Bathymetric surveys since 1965 demonstrate that the sandbars migrate offshore in a cyclic manner, with bar generation near the shore, net offshore migration and bar decay in roughly $4-5 \mathrm{~m}$ water depth. The duration between successive decays is about 4 years. The position reached by the outer bar is just shoreward where it would normally decay (600 - $700 \mathrm{~m}$ from the shore).

The 1998 nourishment was implemented as a broad sandbar feature some $300 \mathrm{~m}$ seaward of the outer-bar zone. It migrated onshore to reach the location of normal outer-bar decay in about 4 years. From 2004, the nourishment was no longer discernible as a clear breakerline, suggesting that it had flattened out. Bathymetric surveys confirm this (Ojeda et al., 2008). The nourishment stopped the net offshore migration of the inner and outer subtidal sandbars, a sandbar response also seen at other nourished locations (e.g., Van Duin et al., 2004; Grunnet and Ruessink, 2005). The 2006 nourishment was implemented on top of the decaying 1998 nourishment and remained in the same location until the end of the study period. Similarly, the subtidal sandbars did not resume their natural net offshore migration.

The 2008 Dijk-in-Duin nourishment can be seen as a sudden seaward jump of the low-tide waterline and the inner bar. This jump is a direct consequence of the nourishment. The outer subtidal bar and the seaward 2006 nourishment were not affected at all. Since 2008, neither the waterline nor the inner subtidal bar showed much long-term variation and thus did not return to their pre-nourishment position. In more detail, Van der Grinten and Ruessink (2012) observed a northward shift of the northern tip of the beach nourishment by approximately $100 \mathrm{~m} /$ year. A similar southward shift of the southern end of the beach nourishment was not observed.

When we consider the time series in Figure 3 in more detail, it is obvious that each series is dominated by slow, multi-year 


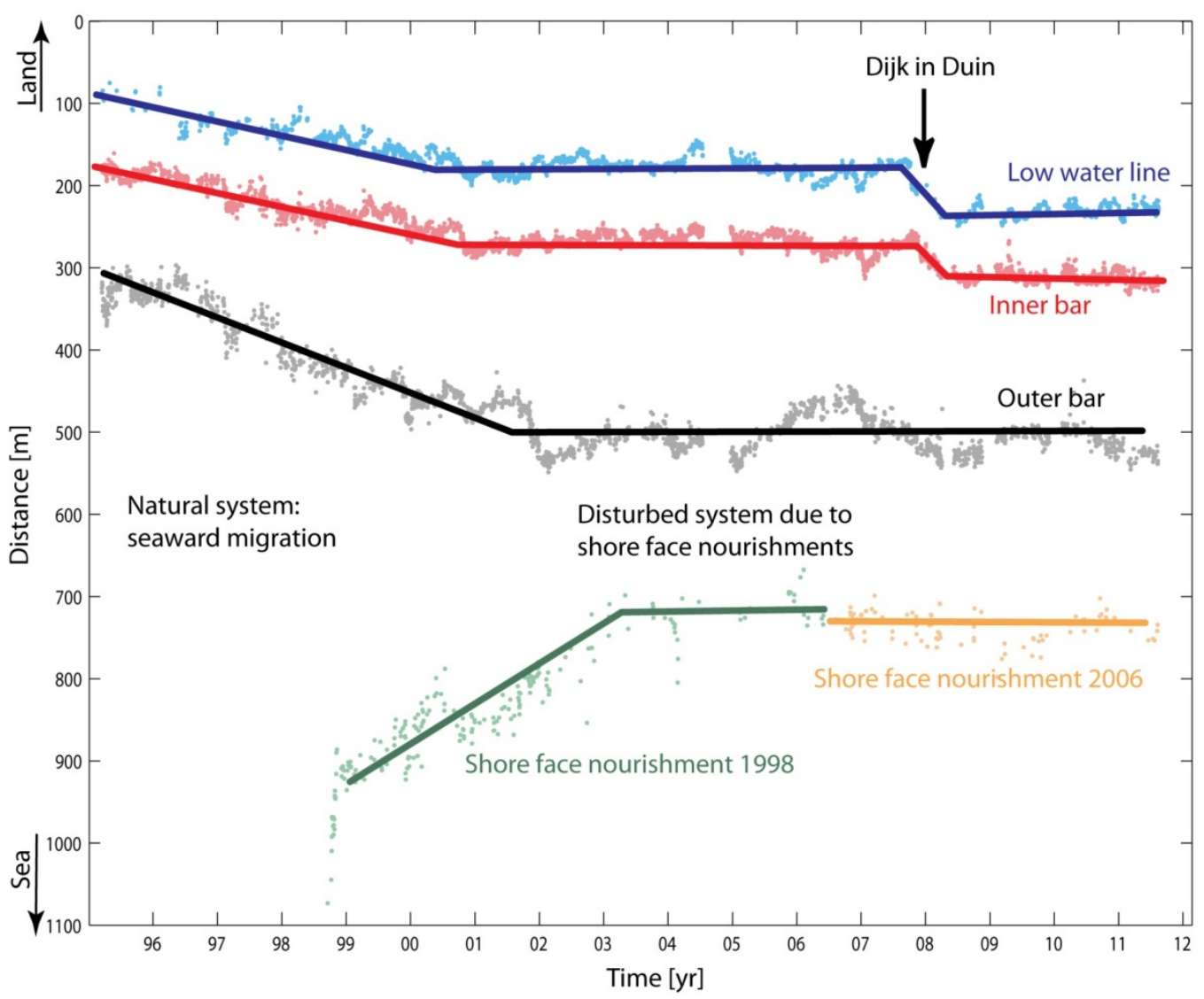

Figure 3. Summary plot of the alongshore-averaged position of the shoreface nourishments, the subtidal sandbars and the low-tide water line versus time. The dots are individual observations, the thick lines are trend lines.

trends. Prior to the first nourishment, this trend was the netoffshore migration, while the first nourishment caused this trend to be replaced by long, irregular oscillations around an otherwise constant position $(250 \mathrm{~m}$ for the inner bar, and $500 \mathrm{~m}$ for the outer bar). Consistent with earlier Noordwijk-based research (e.g., Van Enckevort and Ruessink, 2003), we neither see any marked seasonal variability in sandbar location in response to seasonal variability in the offshore wave conditions, nor a clear response of each bar to storms. The Dijk-in-Duin project has not altered the temporal trends in cross-shore sandbar and waterline behaviour for the time period studied here.

Van der Grinten and Ruessink (2012) further examined the daily migration rate of the two sandbars and the low-tide waterline, where the rate was calculated as the difference in alongshore-averaged position between two consecutive days. The daily migration rates for the outer sandbar were typically largest, while the rates for the low-tide waterline were smallest. Prior to 2007 , some $10 \%$ of the daily rates for the outer sandbar were 0 $\mathrm{m} /$ day, while for the low-tide water line the relative occurrence of $0 \mathrm{~m} /$ day was $25 \%$. After 2007 , the relative occurrence of $0 \mathrm{~m} /$ day was slightly larger for all sandbars and the waterline, for the latter increasing to $35 \%$. Whether this implies that the successive nourishments made the nearshore zone less dynamic, is difficult to say. The increase in $0 \mathrm{~m} /$ day occurrences may also correspond to a difference in wave conditions between the two periods.

\section{Large-scale variability}

The above-mentioned net-offshore-migration of the subtidal sandbars was not always alongshore uniform prior to the implementation of the 1998 nourishment. This means that at one location the outer bar could be migrating offshore, while at another location it could already be decaying. This alongshore variability in outer sandbar migration sometimes caused an initially alongshore continuous inner bar to break up, with one part realigning with an outer bar and the other part with the beach. This large-scale sandbar variability is known as bar switching and in an Argus image looks like forked breakerlines, or bifurcations. Bar switching is thus due to alongshore variation in outer-bar behavior and is an inherent part of the autonomous sandbar behavior at Noordwijk.

The 1998 nourishment resulted in two nourishment-induced bar switches, one of which is shown in Figure 4. The nourishment did not extend along the entire $6 \mathrm{~km}$ of the study area. Shoreward of the nourishment, the sandbars halted their migration, while further to the south and north the net offshore migration continued. At some point, the original inner bar broke at the alongshore location of the head of the nourishment, with the inner bar north and south of the nourishment realigning with the outer bar shoreward of the nourishment. No bar switches were observed following the second shoreface nourishment, probably because it extended along the entire study area and thus did not lead to alongshore variation in 


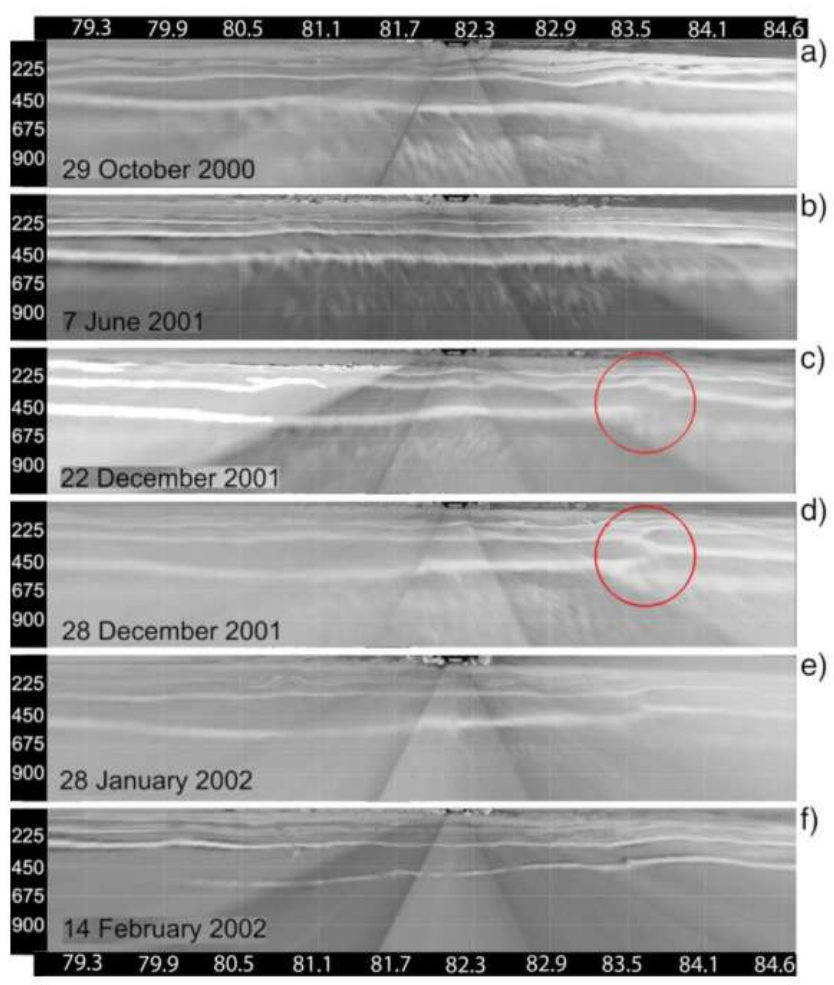

Figure 4. Planview images showing the evolution of a bar switch to the south of the 1998 nourishment. The actual switch is visible as the forked barlines in the red circles. Modified from Ojeda et al. (2008).

outer-bar behaviour. Also, the Dijk-in-Duin nourishment did not result in bar switching, because, as already noted from Figure 3, it did not affect the outer bar.

Another type of large-scale variability is the occasionally loosening of a section of a sandbar (with an alongshore length of several hundreds of meters) and its subsequent onshore migration to merge with a more shoreward sandbar. This loosened part of a sandbar is known as a shoreward propagating accretionary wave (SPAW), and is an inherent part of autonomous sandbar behaviour. We observed one SPAW following the Dijk-in-Duin project, but we believe it to be a natural phenomenon rather than a nourishment-induced feature.

\section{Small-scale variability}

The extracted barlines are rarely perfectly straight; instead, they contain all sorts of alongshore variability, ranging from gentle undulations as in Figure 2 to much more pronounced (in the crossshore) perturbations related to rip channels. Van Enckevort and Ruessink (2003) demonstrated that during the pre-nourishment period rip channels had typical alongshore wavelengths of severalhundreds of meters. Furthermore, the rip features possessed rather long life times, in the order of several months, implying that they did not necessarily disappear during a storm.

Figure 5 shows the standard deviation of the inner-bar lines versus time. The standard deviation is a measure of the magnitude of the alongshore variations in the barline, with larger numbers corresponding to more pronounced variability. The colour coding indicates the number of rips, where a rip was defined as a seaward perturbation with a cross-shore extent of at least $25 \mathrm{~m}$. As can be seen, rather small standard deviations corresponds to a low number of rips. Clearly, the standard deviation and the number of rips vary with time, but there are no breaks in trend in either 2006 (shoreface nourishment) or in 2007/2008 (beach nourishment). From this we can conclude that the nourishments did neither affect the degree of alongshore variation in the inner barline nor the number of rips.

Van der Grinten and Ruessink (2012) additionally observed that, consistent with the observations by Van Enckevort and Ruessink (2003), the rip life times was in the order of months. Furthermore, they observed the rips to migrate both to the north and to the south at rates up to $10 \mathrm{~m} /$ day. The migration direction was consistent with the angle of incidence, with waves from the northwest (southwest) causing rip migration to the south (north). This suggests that the alongshore current driven by obliquely incident breaking waves is the main mechanism for alongshore rip migration.

\section{DISCUSSION}

When we compare the effect of the various nourishments on sandbar and low-tide waterline evolution, it is obvious that the first shoreface nourishment influenced the coast most. It caused the net offshore sandbar migration to stop and resulted in two bar switches. The second shoreface nourishment, which was more extensive in the alongshore direction, prevented the sandbars from resuming their net offshore trend, but did not result in bar switches. Finally, the beach nourishment affected the inner sandbar and the low-tide waterline only during the actual nourishment implementation. It is possible that the subsequent inert behaviour of the inner bar and low-tide water line is caused by the sand brought into the nearshore system by the shoreface nourishments. Because the sandbars at Noordwijk are, relative to other sites along the Dutch coast, rather small in volume, all this sand has, in a manner of speaking, made the nearshore rather inert, see Ojeda et al. (2008) for further discussion. It is very well possible that beach nourishments unprotected by sandbars and/or shoreface nourishments are much more dynamic.

In Noordwijk, we found that the amount of small-scale alongshore variability (e.g., rips) did not change in response to the various nourishments. This differs from the Terschelling nourishment, which caused a break-up of a shoreward located bar into several sections intersected by deep, obliquely oriented channels (Grunnet and Ruessink, 2005). That nourishment was implemented inside the bar zone, rather than offshore the bar zone as in Noordwijk. It is possible that the location of the nourishment steers the effect on small-scale alongshore variability.

In this work, we have focused primarily on positions, not on volumes. It is possible to use Argus imagery to extract volumes. For example, it is feasible to detect water lines at different stages of the tide to build up a digital elevation model of the intertidal zone (e.g., Aarninkhof et al., 2003). Similarly, breaking patterns can be inverted into depth estimates (e.g., Van Dongeren et al., 2008). Neither of these two techniques are, in their present state, fully automated and are insufficiently validated because of a clear lack of bathymetric monitoring data. Nonetheless, they hold great promise for the future. Ideally, one could combine daily to weekly video-based estimates of bathymetry with a waves-currents-sand transport-coastal evolution model to set up an operational 


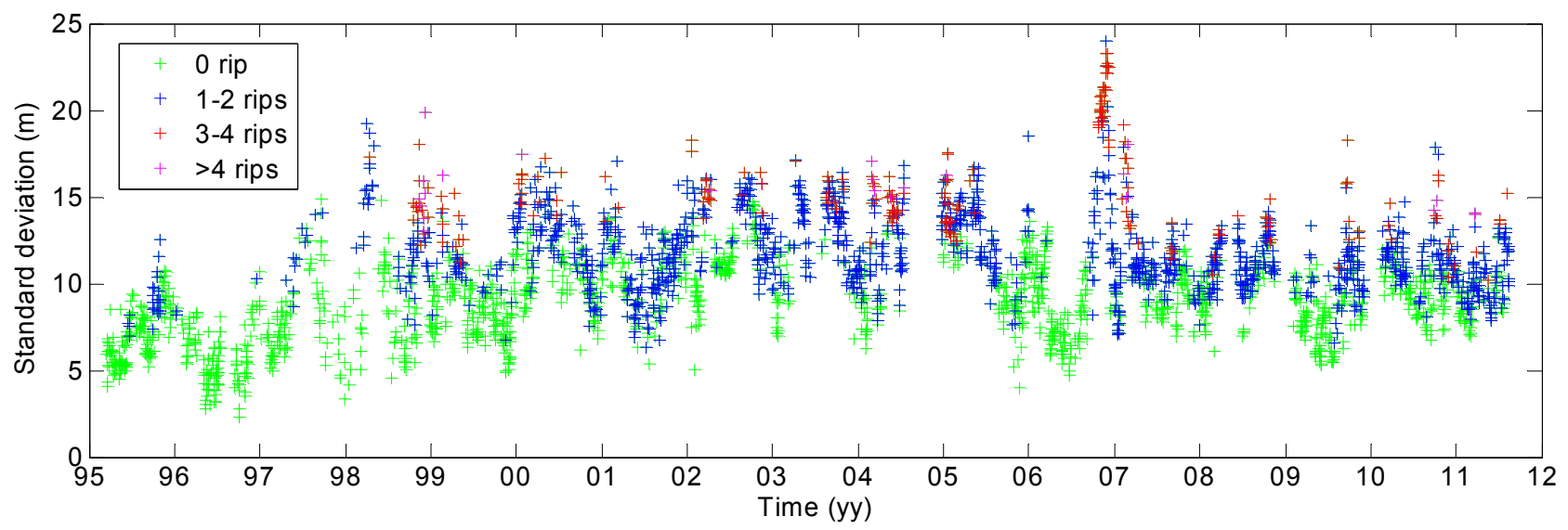

Figure 5. Time series of the standard deviation of inner-bar variability with alongshore wave lengths $<2000 \mathrm{~m}$. The color indicates the number of rips, with a rip being defined as a seaward perturbation of at least $25 \mathrm{~m}$

prediction model for coastal evolution. Such a system might be very useful to predicatively understand large-scale human activities in the coastal zone, such as the Sand Engine.

\section{CONCLUSIONS}

Based on the analysis of an approximately 16-year long data set of daily low-tide planview video image, we conclude that the two shoreface nourishments and the Dijk-in-Duin beach nourishment affect the nearshore sandbars and the low-tide water line in the following ways:

1. The first shoreface nourishment, implemented in 1998, stopped the autonomous, net offshore migration of the inner and outer subtidal sandbar. The sandbars did not resume their natural offshore directed trend, probably because of the second (2006) nourishment. The beach nourishment caused an immediate $50-\mathrm{m}$ seaward shift of the low-tide waterline and of the inner bar, but it did not affect the outer bar. By the end of the study period, some 2.5 years after the beach nourishment, neither the low-tide waterline nor the inner bar had returned to their original position. The northern end of the beach nourishment migrated north by approximately 100 $\mathrm{m} /$ year. A similar southward shift at the southern end of the nourishment was not observed.

2. The first shoreface nourishment caused alongshore variable cross-shore migration rates of the outer-bar along the coast. In front of the nourishment, the migration rates were near 0 , while to the north and south of the nourishment, the net offshore migration continued. After several years, this caused two bar switches. We also observed one shoreward propagating accretionary wave after the beach nourishment, but this feature is likely to be a natural phenomenon rather than nourishment-induced.

3. We did not find any evidence that either the shoreface nourishments or the Dijk-in-Duin beach nourishment affected the small-scale variability in the barlines, for example, in terms of the number of rips.

\section{REFERENCES}

Aarninkhof, S.G.J., I.L. Turner, T.D.T. Dronkers, M. Caljouw and L. Nipius, 2003. A video-based technique for mapping intertidal beach bathymetry. Coastal Engineering, 49, 275-289.

Den Heijer, C., F. Baart and M. van Koningsveld, in press. Assessment of dune failure along the Dutch coast using a fully probabilistic approach. Geomorphology.

Grunnet, N.M. and B.G. Ruessink, 2005. Morphodynamic response of nearshore bars to a shoreface nourishment. Coastal Engineering, 52, 119-137.

Ojeda, E, B.G. Ruessink and J. Guillen, 2008. Morphodynamic response a two-barred beach to a shoreface nourishment. Coastal Engineering, 55, 1185-1196.

Pape, L., N.G. Plant and B.G. Ruessink, 2010. On cross-shore migration and equilibrium states of nearshore sandbars. Journal of Geophysical Research, 115, doi:10.1029/2009JF001501.

Van der Grinten, R.M. and B.G. Ruessink, 2012. Evaluatie van de kustversterking bij Noordwijk aan Zee - De invloed van de versterking op de zandbanken. Internal UU Report (In Dutch).

Van Dongeren. A., N. Plant, A. Cohen, D. Roelvink, M.C. Hallar, and P.A. Catalan, 2008. Beach Wizard: nearshore bathymetry estimation through assimilation of model computations and remote observations. Coastal Engineering, 55, 1016-1027.

Van Duin, M.J.P., N.R. Wiersma, D.J.R. Walstra, L.C. van Rijn, M.J.F. Stive, 2004. Nourishing the shoreface: observations and hindcasting of the Egmond case, The Netherlands. Coastal Engineering, 51, 813-837.

Van Enckevort, I.M.J. and B.G. Ruessink, 2001. Effect of hydrodynamics and bathymetry on video estimates of nearshore sandbar position. Journal of Geophysical Research, 106, 16,96916,980 .

Van Enckevort, I.M.J. and B.G. Ruessink, 2003. Video observations of nearshore bar behaviour. Part 2: alongshore non-uniform variability. Cont. Shelf Research, 23,513-532.

Wijnberg, K.M. and J.H.J. Terwindt, 1995. Extracting decadal morphological beahaviour from high-resolution, long-term bathymetric surveys along the Holland coast using eigenfucntion analysis. Marine Geology, 126, 301-330.

Wijnberg, K.M. and R.A. Holman, 2007. Video-observations of shoreward propagating accretionary waves. Proceedings of RCEM 2007, 737-743. 